\title{
Sistem Pendukung Keputusan Konsentrasi dan Peminatan Prodi Teknik Informatika Universitas Janabadra Yogyakarta
}

\author{
Decision Support System for Informatics Speciality \\ in Janabadra University Yogyakarta
}

\author{
Yumarlin MZ \\ Universitas Janabadra \\ E-mail: yumarlin@janabadra.ac.id
}

\begin{abstract}
Abstrak
Penentuan konsentrasi dan peminatan prodi Teknik Informatika Universitas Janabadra Yogyakarta yang akan diterapkan diharapkan dapat mempermudah mahasiswa dalam menentukan tugas akhir yang sesuai. Konsentrasi dan peminatan ini akan mulai dilaksanakana mahasiswa yang telah memasuki semester 5, berguna bagi mahasiswa untuk mengembangkan kemampuan dirinya menjadi lebih baik lagi. Untuk membantu penentuan konsentrasi dan peminatan mahasiwa yang terbaik maka dibutuhkan sebuah sistem pendukung keputusan. Dalam proses pembuatan sistem pendukung keputusan konsentrasi dan peminatan, mengggunakan metode Fuzzy Multiple Attribute Decission Making (FMADM) dengan metode Simple Additive Weighting $(S A W)$. Metode ini di pilih karena mampu menyeleksi alternative terbaik dari sejumlah alternatif, dalam hal ini alternatif yang dimaksudkan yaitu konsentrasi dan peminatan yang baik berdasarkan kriteria-kriteria yang ditentukan. Penelitian dilakukan dengan mencari nilai bobot untuk setiap kriteria, kemudian dilakukan proses perankingan yang akan menentukan alternatif yang memiliki nilai tertinggi, yaitu jalur peminatan yang sesuai berdasarkan nilai-nilai akademik dari semester 1 sampai semester 4.
\end{abstract}

Kata Kunci - Konsentrasi dan Peminatan, sistem pendukung keputusan, SAW

\begin{abstract}
Determination of concentration and specialization department of Information Engineering University of Yogyakarta, which will be applied Janabadra expected to facilitate the students to determine the appropriate final task. Concentration and this stream will start dilaksanakana students who have entered the 5th semester, is useful for students to develop the ability of itself to be better again. To assist in determining the concentration and specialization of the best students we need a decision support system. In the process of making a decision support system of concentration and specialization, use traditional methods of Fuzzy Multiple Attribute Making Decission (FMADM) with Simple Additive weighting method (SAW). This method was chosen because it is able to the best alternative from a number of alternatives, in this case the alternative meant that concentration and specialization are both based on the criteria specified. Research done by finding the weight values for each criterion, then do a ranking process that will determine the alternative that has the highest value, the corresponding specialization path based on the academic values of the 1st semester to semester 4.
\end{abstract}

Keywords - Concentration and Specialisation, decision support systems, SAW 


\section{PENDAHULUAN}

Globalisasi telah mengakibatkan keseluruhan kehidupan bermasyarakat, tidak terkecuali sektor pendidikan dan ketenagakerjaan. Mobilitas mahasiswa memberikan tantangan bagi perguruan tinggi untuk memperoleh pengakuan dari masyarakat global terhadap hasil pendidikan yang dilakukannya. Sesuai ketentuan yang tercantum dalam Standar Nasional Pendidikan Tinggi (SN DIKTI) tahun 2014, setiap program studi wajib dilengkapi dengan target capaian pembelajaran.[1] Dasar hukum capaian pembelajaran dinyatakan di dalam Peraturan Presiden Nomor 8 Tahun 2012 tentang Kerangka Kualifikasi Nasional Indonesia (KKNI) yaitu kerangka penjenjangan kualifikasi kompetensi yang dapat menyandingkan, menyetarakan, dan mengintegrasikan antara bidang pendidikan dan bidang pelatihan kerja serta pengalaman kerja dalam rangka pemberian pengakuan kompetensi kerja.

Institusi pendidikan seperti Universitas kerap kali membutuhkan suatu bentuk keputusan dalam menentukan konsentrasi dan peminatan yang sesuai untuk para mahasiswanya sehingga tercapai pembelajaran yang baik sesuai dengan minat mahasiswa. Keputusan yang diambil dalam menentukan konsentrasi dan peminatan mungkin hampir benar sesuai dengan minat, nilai akademik dan pendukung mahasiswa atau mungkin bisa saja salah. Keputusan merupakan suatu hal yang sangat berpengaruh dalam proses menghadapi alternatif yang dipilih, begitu juga memilih konsentrasi dan peminatan program studi yang berdampak pada fokus penelitian untuk tugas akhir mahasiswa. Tetapi memang tidaklah mudah untuk menentukan konsentrasi dan peminatan karena keterbatasan informasi yang di miliki mahasiswa. Berbagai kendala dalam menentukan konsentrasi dan peminatan yang sesuai dengan kriteria memang cukup membingungkan, apalagi kalau mahasiswa tersebut hanya ikut-ikutan temannya dalam menentukan, kurangnya percaya diri dengan kemampuan yang dimiliki.

Berdasarkan permasalahan di atas maka penulis menganggap bahwa sistem pendukung keputusan konsentrasi dan peminatan ini perlu digunakan, untuk lebih memudahkan mahasiswa teknik informatika yang akan melanjutkan kesemester yang lebih tinggi sehingga memusatkan bidang studi yang akan ditekuninya nanti. Karena selama ini program studi teknik informatika belum menerapkan sistem menentukan konsentrasi dan peminatan tersebut, sehingga diharapkan dapat diterapkan pada kurikulum semester baru program studi teknik informatika, agar dapat memudahkan para mahasiswa yang akan mengambil Tugas Akhir, dan dapat terfokus untuk mengambil penelitian tentang konsentrasi dan minat yang ada. Karena selama ini para mahasiswa sering kerepotan atau bingung untuk memilih tentang apa yang akan digunakan untuk bahan penelitian. Sehingga dengan adanya sistem pendukung keputusan konsentrasi dan peminatan ini diharapkan dapat membantu dan memudahkan mahasiswa program studi teknik informatika Universitas Janabadra untuk menentukan konsentrasi dan minatnya.

Model yang digunakan dalam sistem pendukung keputusan ini adalah Fuzzy Multiple Attribute Decision Making (FMADM) dengan menggunakan metode SAW. Metode SAW ini dipilih karena metode ini menentukan nilai bobot untuk setiap atribut atau kriteria, kemudian dilanjutkan dengan proses perankingan yang akan menyeleksi alternatif terbaik dari sejumlah alternatif, dalam hal ini alternatif yang dimaksud adalah penentuan jalur peminatan bagi mahasiswa berdasarkan kriteria-kriteria yang ditentukan. Dengan metode perangkingan tersebut, diharapkan penilaian akan lebih tepat karena didasarkan pada nilai kriteria dan bobot yang sudah ditentukan sehingga akan mendapatkan hasil yang lebih akurat untuk menentukan konsentrasi dan peminatan mahasiswa program studi teknik informatika. Rumusan masalah yang dikemukakan berdasarkan dari fokus kajian yang akan dibahas sehingga akan memudahkan untuk di teliti. Berdasarkan latar belakang masalah yang telah di papar diatas dapat dirumuskan permasalahan yang akan diselesaikan yaitu "Bagaimana merancang sistem pendukung keputusan konsentrasi dan peminatan program studi teknik Informatika Universitas Janabadra, sehingga dapat membantu mahasiswa menentukan dan memudahkan pengambilan dalam penelitian tugas akhir mahasiswa menggunakan FMADM dengan metode SAW".

Penelitian ini bertujuan untuk merancang dan membangun sistem pengambilan keputusan dengan menggunakan FMADM dengan metode Simple Additive Weighting (SAW) untuk 
menentukan konsentrasi dan peminatan program studi teknik informatika Universitas Janabadra Yogyakarta berdasarkan dengan mempertimbangkan nilai - nilai akademik dari semester 1 sampai semester 4 terhadap konsentrasi dan peminatan yang sesuai.

\subsection{Tinjauan Pustaka}

Beberapa acuan referensi penelitian yang digunakan dalam melakukan penelitian ini sebagai pembanding. Diantaranya Penentuan Peminatan Tugas Akhir Mahasiswa Teknik Informatika Unsika oleh Sofi De Fiyanti dengan menggunakan metode clustering dengan algor itma $\mathrm{K}$-means dapat menentukan sebaran peminatan tugas akhir pada program studi Teknik Infor matika berdasarkan nilai- nilai matakuliah yang telah ditempuh. Pemodelan yang akan dibangun dengan memanfaatkan aplikasi data mining. Claster yang digunakan adalah 3 (tiga) kategori dengan pertimbangan peminatan tugas akhir yang ada di program studi Teknik Informatika. [2]

Selain itu Penelitian yang berjudul Penentuan Minat pada Program Studi Teknik Informatika Universitas Muhammadiyah Purwokerto Menggunakan Teori Dempster-Shafer Oleh Reza Satria dan Hindayati Mustafidah mengkaji tentang menentukan minat yang sesuai dengan kemampuan akademik mahasiswa dengan metode Dempster-Shafer. Dengan metode DempsterShafer, mampu mengatasi ketidakpastian penambahan suatu fakta baru dalam menentukan suatu keputusan. Hal ini menegaskan bahwa teori Dempster-Shafer sangat tepat untuk diterapkan di penelitian ini, karena kurikulum merupakan suatu hal yang dapat mengalami perubahan sewaktuwaktu. [3]

Dalam Penelitian yang dilakukan Y J Wang pada tahun 2015 dengan judul A fuzzy multicriteria decision-making model based on simple additive weighting method and relative preference relation, mengkaji SAW yang diterapkan di lingkungan fuzzy, untuk menggeneralisasi SAW bawah lingkungan fuzzy dalam mengatasi kelemahan perkalian fuzzy. Dengan memanfaatkan hubungan preferensi relatif yaitu dari hubungan preferensi fuzzy SAW. Dalam penelitian ini mengusulkan model FMCDM berdasarkan SAW dan preferensi hubungan relatif mudah dan cepat memecahkan masalah FMCD. [4]

Elvia Budianita dan Ulti Desi Arni dalam penelitiannya menjelaskan kajian tentang Penentuan bidang konsentrasi studi tugas akhir diharapkan dapat mempermudah mahasiswa dalam menentukan bidang tugas akhirnya sesuai dengan pola nilai mata kuliah yang diambilnya. Banyaknya bidang tugas akhir membuat mahasiswa merasa bingung menentukan tema tugas akhirnya. Sehingga banyak mahasiswa menentukan bidang konsentrasi studi tugas akhirnya diluar mata kuliah yang mereka ambil. Untuk membantu mahasiswa dalam menentukan bidang tugas akhirnya yang sesuai dengan pola nilai mata kuliah yang diambil. Metode yang digunakan yaitu Metode Learning Vector Quantization (LVQ). Dengan mengambil Studi Kasus: Mahasiswa Teknik Informatika UIN Suska Riau. [5]

\subsection{Sistem Pendukung Keputusan}

Sistem pendukung keputusan atau decision support system (DSS) adalah suatu sistem informasi untuk membantu manajer dalam proses pengambilan keputusan setengah terstruktur (semi structured) supaya lebih efektif dengan menggunakan model-model analitis dan data yang tersedia [6]. Menurut Keen dan Scoot Morton, Sistem pendukung keputusan merupakan penggabungan sumber-sumber kecerdasan individu dan kemampuan komponen untuk memperbaiki kualitas keputusan. Sistem penunjang pendukung keputusan adalah salah satu cara mengorganisir informasi yang dimaksudkan untuk digunakan dalam membuat keputusan. [7]

\subsection{FMADM (Fuzzy Multiple Attribute Decision Making)}

Fuzzy multiple Attribute Decision Making (FMADM) adalah suatu metode yang digunakan untuk mencari alternatif dengan kriteria tertentu. Inti dari FMADM adalah menentukan nilai bobot untuk setiap atribut, kemudian dilanjutkan dengan proses perankingan yang sudah diberikan. 
Pada dasarnya ada 3 pendekatan untuk mencari bobot atribut, yaitu:

1. Pendekatan subyektif,

2. obyektif dan

3. Pendekatan integrasi antara subyektif dan objektif.

Masing-masing pendekatan memiliki kelebihan dan kelemahan. Pada pendekatan subyektif, nilai bobot ditentukan berdasarkan subyektifitas dari para pengambil keputusan, sehingga beberapa faktor dalam proses perankingan alternatif bisa ditentukan secara bebas. Sedangkan pada pendekatan obyektif, nilai bobot dihitung secara matematis sehingga mengabaikan subyektifitas dari pengambil keputusan. [8] Model ini memang mudah untuk diimplementasikan, namun kita sangat dimungkinkan untuk kehilangan beberapa informasi terutama yang menyangkut ketidakpastian. Penggunaan relasi preferensi fuzzy lebih menjamin ketidak pastian yang melekat pada bilangan fuzzy hingga proses perankingan.

\section{METODE PENELITIAN}

\subsection{Metode Pengembangan Sistem}

Metodologi adalah rincian secara menyeluruh dari siklus pengembangan sistem informasi yang mencakup langkah demi langkah tugas dari masing-masing tahapan, aturan yang harus dijalankan oleh individu dan kelompok dalam melaksanakan tugas, standar kualitas dan pelaksanaan dari masing-masing tugas, teknik-teknik pengembangan yang digunakan untuk masing-masing tugas ini berkaitan dengan teknologi yang digunakan oleh pengembang. Metode yang digunakan dalam perancangan dan pengembangan suatu aplikasi sistem informasi pada umumnya mengacu pada tahapan pengembangan sistem.

Metode waterfall merupakan metode yang sering digunakan oleh penganalisa sistem pada umumnya. Inti dari metode waterfall adalah pengerjaan dari suatu sistem dilakukan secara berurutan atau secara linear. [9] Jadi jika langkah kesatu belum dikerjakan maka belum melanjutkan atau melakukan pengerjaan langkah 2, 3 dan seterusnya. Secara otomatis tahapan ke-3 akan bisa dilakukan jika tahap ke-1 dan ke-2 sudah dilakukan. Metode Waterfall dapat dilihat pada Gambar 1 berikut ini:

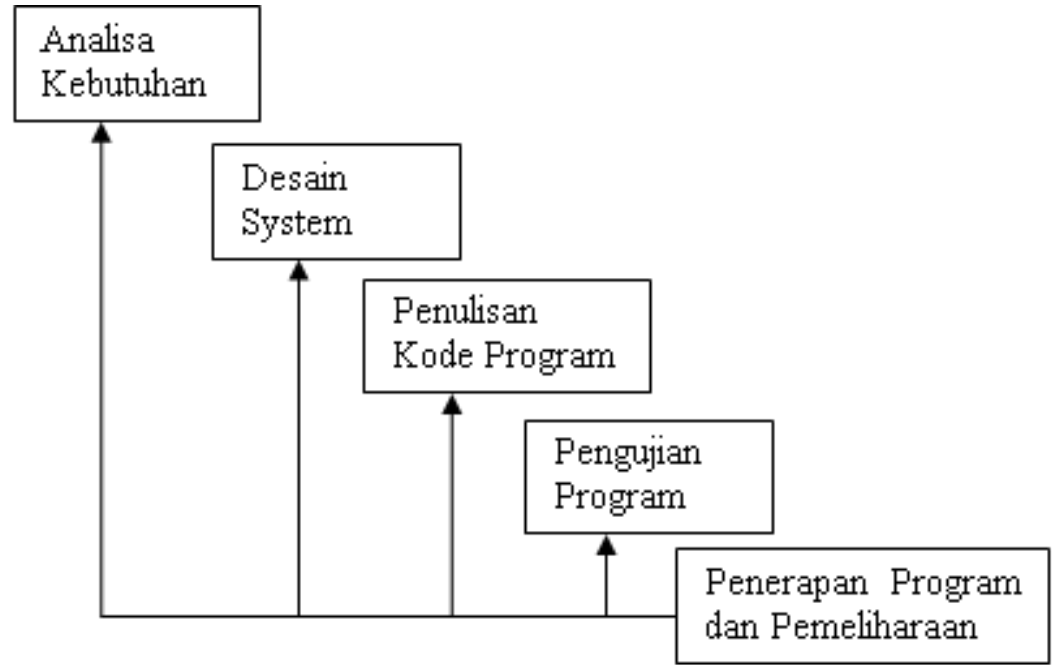

Gambar 1. Metode Waterfall 
Secara garis besar metode waterfall memiliki langkah - langkah sebagai berikut:

1. Analisa Kebutuhan

Langkah ini merupakan analisa terhadap kebutuhan sistem. Pengumpulan data dalam tahap ini bisa dilakukan saat wawancara atau studi literatur. Dimana Peneliti akan menggali informasi sebanyaknya-banyaknya terhadap pengguna sehingga akan tercipta sebuah sistem yang bisa melakukan tugas-tugas yang diinginkan. Tahapan ini akan menghasilkan dokumen user requiretment atau sebagai data yang berhubungan dengan keinginan user dalam pembuatan sistem. Dokumen ini lah yang akan menjadi acuan peneliti untuk menerjemahkan ke dalam bahasa pemprogram.

2. Desain Sistem

Proses desain akan menterjemahkan syarat kebutuhan ke sebuah perancangan perangkat lunak yang dapat diperkirakan sebelum dibuat coding. Tahapan dimana dilakukan penuangan pikiran dan perancangan sistem terhadap solusi dari permasalahan yang ada dengan menggunakan perangkat pemodelan sistem seperti diagram alir data (data flow diagram), diagram hubungan entitas (entity relationship diagram) serta struktur dan bahasa pemograman.

3. Penulisan Kode Program

Penulisan kode program merupakan penerjemahan desain dalam bahasa pemograman yang bisa dikenali oleh komputer oleh programmer. Tahapan inilah yang merupakan tahapan secara nyata dalam mengerjakan suatu sistem. Dalam artian penggunaan komputer akan dimaksimalkan dalam tahapan ini. Setelah pengkodean selesai maka akan dilakukan testing dengan tujuan menemukan kesalahan-kesalahan terhadap sistem tersebut dan kemudian untuk diperbaiki.

4. Pengujian program

Dalam tahap ini unit program yang telah dibuat dan valid akan diintegrasikan dengan unit program lainnya, dan kemudian dilakukan pengujian secara keseluruhan. Tujuan dari tahap ini adalah untuk menjamin program yang dibuat dapat terintegrasi dengan baik dan siap digunakan oleh pengguna.

5. Penerapan Program dan Pemeliharaan

Tahap ini bisa dikatakan tahap final pembuatan sistem, setelah melakukan analisa data, desain dan pengkodean maka sistem yang sudah jadi dapat digunakan. Perangkat lunak yang sudah disampaikan ke pada pengguna (user) pasti akan mengalami perubahan. Perubahan tersebut bisa terjadi jika, mengalami kesalahan karena harus menyesuaikan dengan lingkungan (periperal atau sistem operasi baru) atau disebabkan user membutuhkan perkembangan fungsional.

\subsection{Pemodelan Proses Data Flow Diagram (DFD)}

Dalam pemodelan proses akan digambarkan diagram aliran data dan proses yang terjadi secara logic. Desain aliran data dalam sistem pendukung keputusan jalur peminatan ini ditunjukkan pada Gambar 2 dan Gambar 3 berikut ini. 
1. Context Diagram

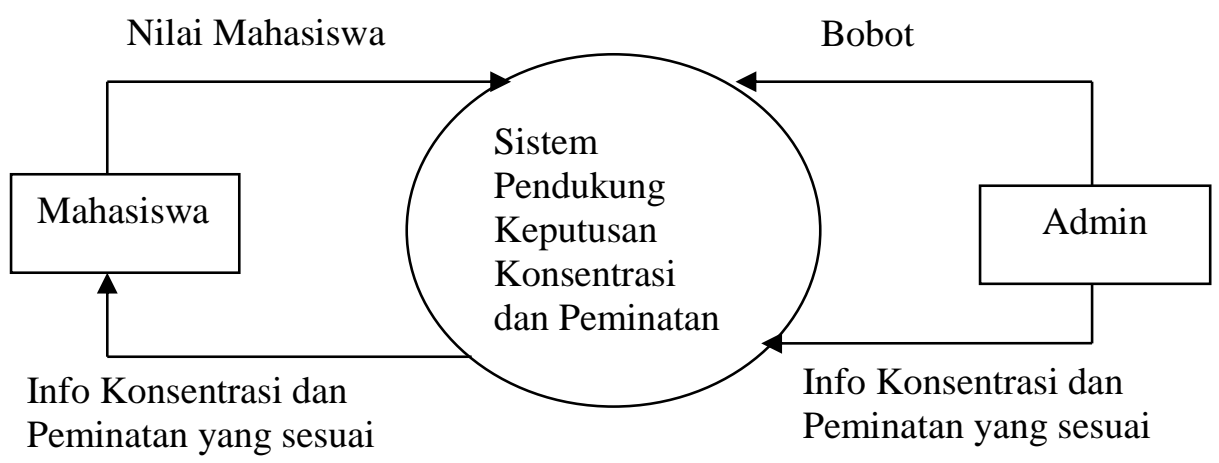

Gambar 2. Context Diagram Sistem Pendukung Keputusan Konsentrasi dan Peminatan

2. DFD Level 0

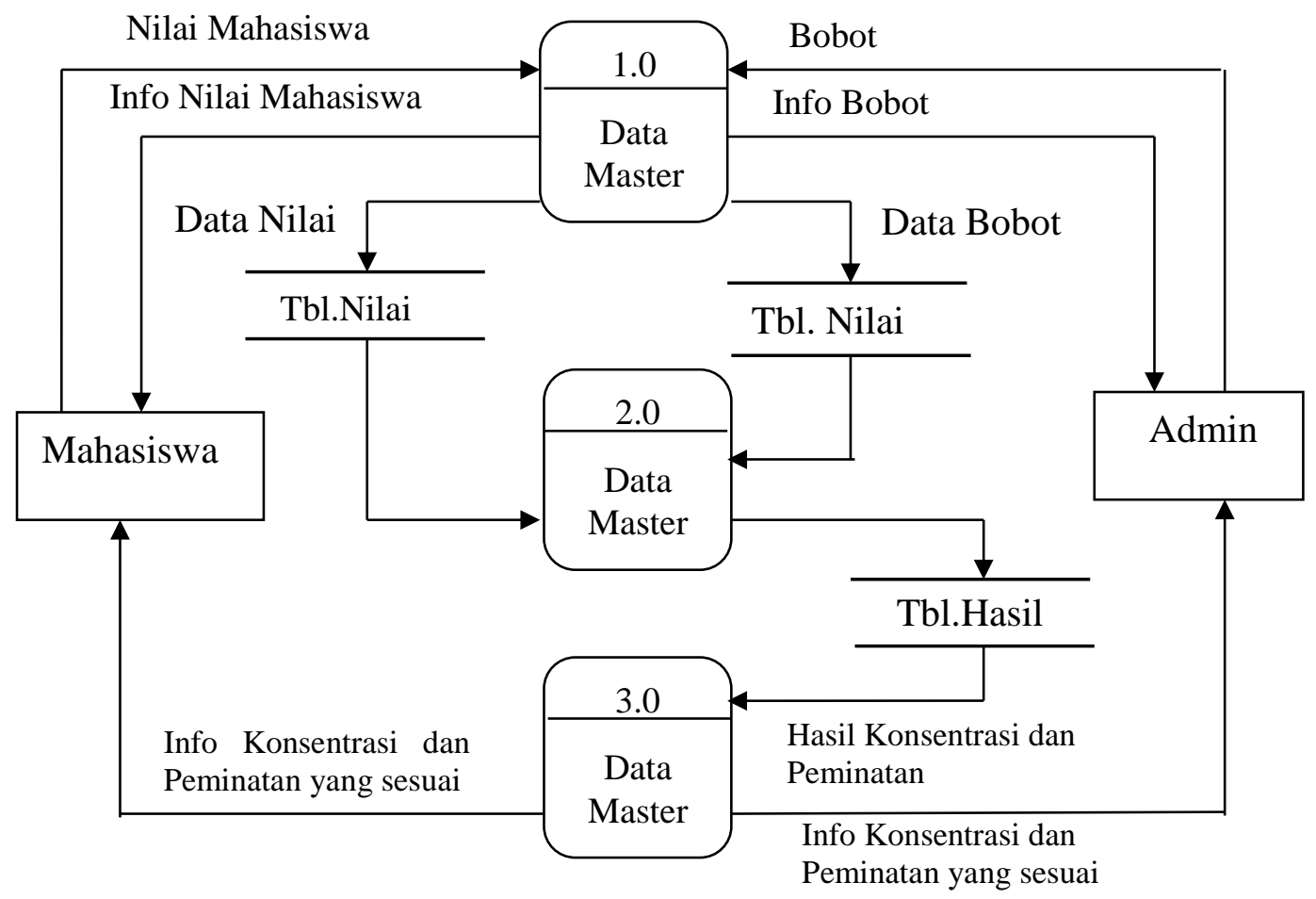

Gambar 3. DFD Level 0 Sistem Pendukung Keputusan Konsentrasi dan Peminatan 


\subsection{Implementasi Fuzzy}

1. Alternatif yang menentukan

Dalam metode penelitian ini ada 3 alternatif yang menentukan konsentrasi dan peminatan apa yang paling sesuai terhadap mahasiswa tersebut. Adapun alternatifnya yakni:

A1: Database Adminitration, A2: Pemograman Mobile dan A3: Network dan Security.

2. Kriteria yang dibutuhkan

Dalam metode penelitian ini bobot dan kriteria yang dibutuhkan untuk menentukan konsentrasi dan peminatan yang paling sesuai dengan mahasiswa berdasarkan dari mata kuliah yang sudah ditentukan terdapat 12 mata kuliah sebagai kriteria.

Rating kecocokan setiap alternatif pada setiap kriteria ditunjukkan pada Gambar 4, dinilai dengan 1 sampai 3 yaitu 1 menunjukkan Kurang berpengaruh (KB), 2 menunjukkan Cukup Berpengaruh (CB) dan 3 menunjukkan Berpengaruh (B).

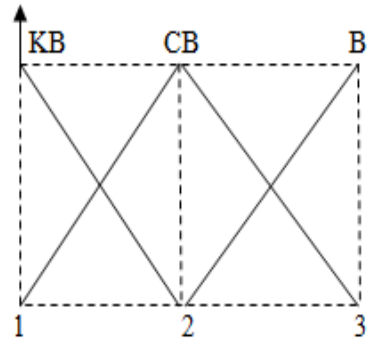

$$
\begin{aligned}
& \mathrm{KB}=1 \\
& \mathrm{CB}=2 \\
& \mathrm{~B}=3
\end{aligned}
$$

Gambar 4. Bilangan fuzzy rating kecocokan setiap alternatif

Sedangkan tingkat kepentingan setiap kriteria ditunjukkan pada Gambar 5, dinilai dengan bobot 1 sampai 5 yang ditunjukkan pada Tabel 1 .

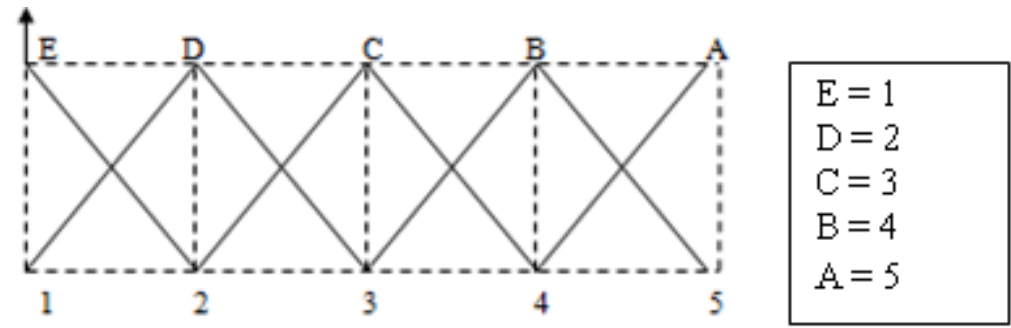

Gambar 5. Bilangan fuzzy bobot

Tabel 1. Bobot Setiap Kriteria

\begin{tabular}{|l|l|l|}
\hline Nilai & Bobot & \multicolumn{1}{|c|}{ Keterangan } \\
\hline A & 5 & Sangat Baik \\
\hline B & 4 & Baik \\
\hline C & 3 & Cukup \\
\hline D & 2 & Kurang \\
\hline E & 1 & Sangat Kurang \\
\hline
\end{tabular}




\section{4. $S A W$}

Menurut Fishburn dalam membangun sistem pendukung keputusan ini akan diterapkan metode SAW dalam menyelesaikan masalah Multi Attribute Decision Making yang dihadapi. Metode SAW sering juga dikenal istilah metode penjumlahan terbobot. Konsep dasar metode SAW adalah mencari penjumlahan terbobot dari rating kinerja pada setiap alternatif pada semua atribut. Metode SAW membutuhkan proses normalisasi matriks keputusan (X) ke suatu skala yang dapat diperbandingkan dengan semua rating alternatif yang ada.

Berikut adalah persamaan yang ada dalam metode SAW. [8]

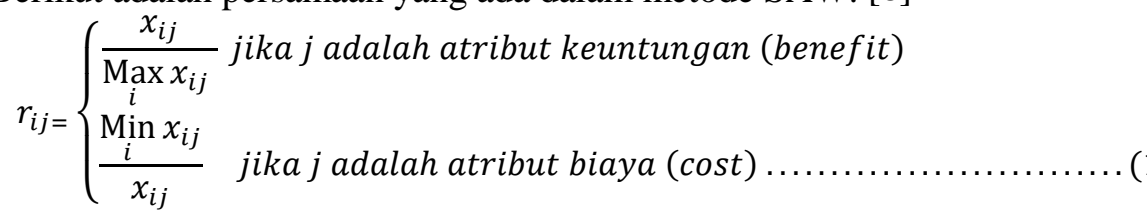

dengan $r_{i j}$ adalah rating kinerja ternormalisasi dari alternatif $A_{i}$ pada atribut $C_{j} ; i=1,2, \ldots, m$ dan $j=1,2, \ldots, n$. Untuk menentukan nilai preferensi untuk setiap alternatif $\left(V_{i}\right)$ diberikan sebagai:

$$
V_{i}=\sum_{j=1}^{n} w_{j} r_{i j}
$$

Nilai $\mathrm{V}_{\mathrm{i}}$ yang lebih besar mengindikasikan bahwa alternatif $\mathrm{A}_{\mathrm{i}}$ lebih terpilih.

\subsubsection{Analisis Metode SAW}

Tahap-tahap yang dilakukan pada metode SAW yaitu:

1. Menentukan kriteria yang akan dijadikan acuan dalam pengambilan keputusan, yaitu Ci, seperti ditunjukkan pada Tabel 2.

Tabel 2. Tabel Kriteria

\begin{tabular}{|c|l|}
\hline Kriteria & \multicolumn{1}{|c|}{ Keterangan } \\
\hline C1 & Kalkulus I \\
\hline C2 3 & Dasar Pemograman \\
\hline C3 & Pengantar Teknlogi Informasi \\
\hline C5 & Kalkulus II \\
\hline C6 & Algoritma dan Pemograman \\
\hline C7 & Mikroprosesor \\
\hline C8 & Matematika deskrit \\
\hline C9 & Basis Data I \\
\hline C10 & Sistem Digital \\
\hline C11 & Teori Bahasa dan Otomata \\
\hline C12 & Organisasi Komputer \\
\hline & Basis Data II \\
\hline
\end{tabular}


Citec Journal, Vol. 3, No. 4, Agustus 2016 - Oktober 2016

ISSN: 2460-4259

2. Menentukan rating kecocokan setiap alternative pada setiap kriteria

Berdasarkan data nilai kriteria pada semester 1 s.d 4 dapat dibentuk matriks keputusan

$\mathrm{X}$ yang telah dikonversikan dengan bilangan fuzzy, disajikan dalam Tabel 3.

Tabel 3. Rating Kecocokan Setiap Alternatif Pada Setiap Kriteria

\begin{tabular}{|l|l|l|l|l|l|l|l|l|l|l|l|l|}
\hline \multirow{2}{*}{ Alternatif } & \multicolumn{10}{|c|}{ Kriteria } \\
\cline { 2 - 16 } & C1 & C2 & C3 & C4 & C5 & C6 & C7 & C8 & C9 & C10 & C11 & C12 \\
\hline A1 & 5 & 4 & 3 & 3 & 4 & 3 & 4 & 5 & 2 & 5 & 5 & 4 \\
\hline A2 & 4 & 3 & 3 & 4 & 4 & 3 & 3 & 5 & 5 & 3 & 3 & 4 \\
\hline A3 & 3 & 5 & 2 & 3 & 5 & 5 & 3 & 2 & 4 & 4 & 2 & 5 \\
\hline
\end{tabular}

Penentuan nilai vector bobot berdasarkan tingkat kepentingan masing-masing kriteria pada konsentrasi dan peminatan, dapat dilihat pada Tabel 4. Penentuan Bobot untuk masingmasing kriteria:

Tabel 4. Bobot Setiap Kriteria

\begin{tabular}{|l|l|l|l|l|l|l|l|l|l|l|l|l|}
\hline Kriteria & C1 & C2 & C3 & C4 & C5 & C6 & C7 & C8 & C9 & C10 & C11 & C12 \\
\hline Bobot & 1 & 3 & 2 & 1 & 3 & 2 & 1 & 2 & 3 & 3 & 3 & 3 \\
\hline
\end{tabular}

3. Membuat matriks keputusan berdasarkan criteria (Ci)

Kemudian melakukan normalisasi matriks berdasarkan persamaan yang disesuaikan dengan jenis atribut (atribut keuntungan ataupun atribut biaya) sehingga diperoleh matriks ternormalisasi R. Membuat matriks keputusan X, dibuat dari table kecocokan sebagai berikut:

$$
X=\left\{\begin{array}{llllllllllll}
5 & 4 & 3 & 3 & 4 & 3 & 4 & 5 & 2 & 5 & 5 & 4 \\
4 & 3 & 3 & 4 & 4 & 3 & 3 & 5 & 5 & 3 & 3 & 4 \\
3 & 5 & 2 & 3 & 5 & 5 & 5 & 2 & 4 & 4 & 2 & 5
\end{array}\right.
$$

Pertama, dilakukan normaslisasi matrik X untuk menghitung nilai masing-masing kriteria berdasarkan kriteria diasumsikan, sebagai kriteria keuntungan atau biaya sebagai berikut:

$$
\mathrm{R}=\left\{\begin{array}{llllllllllll}
1 & 0.8 & 1 & 0.75 & 0.8 & 0.6 & 1 & 1 & 0.4 & 1 & 1 & 0.8 \\
0.8 & 0.6 & 1 & 1 & 0.8 & 0.6 & 0.75 & 1 & 1 & 0.6 & 0.6 & 0.8 \\
0.6 & 1 & 0.67 & 0.75 & 1 & 1 & 0.75 & 0.4 & 0.8 & 0.8 & 0.4 & 1
\end{array}\right.
$$

Hasil akhir diperoleh dari proses perankingan yaitu penjumlahan dari perkalian matriks ternormalisasi $\mathrm{R}$ dengan vektor bobot sehingga diperoleh nilai terbesar yang dipilih sebagai alternatif terbaik (Ai) sebagai solusi.

Selanjutnya akan dibuat perkalian matriks $\mathrm{W} * \mathrm{R}$ dan penjumlahan hasil perkalian untuk memperoleh alternatif terbaik dengan melakukan perangkingan nilai terbesar sebagai berikut: $\mathrm{V} 1=(1)(1)+(0.8)(3)+(1)(2)+(0.75)(1)+(0.8)(3)+(0.6)(2)+(1)(1)+(1)(2)+(0.4)(3)+(1)(3)+(1)(3)+(0.8)(3)=22.35$ $\mathrm{V} 2=(0.8)(1)+(0.6)(3)+(1)(2)+(1)(1)+(0.8)(3)+(0.6)(2)+(0.75)(1)+(1)(2)+(1)(3)+(0.6)(3)+(0.6)(3)+(0.8)(3)=20.95$ $\mathrm{V} 3=(0.6)(1)+(1)(3)+(0.67)(2)+(0.75)(1)+(1)(3)+(1)(2)+(0.75)(1)+(0.4)(2)+(0.8)(3)+(0.8)(3)+(0.4)(3)+(1)(3)=21.23$

Hasil Perangkingan diperoleh: V1 $=22.35, \mathrm{~V} 2=20.95, \mathrm{~V} 3=21.23$. Nilai terbesar ada pada V1 dengan demikian alternative A1 adalah Alternatif yang terpilih sebagai Alternatif terbaik. 


\section{HASIL DAN PEMBAHASAN}

\subsection{Hasil Pengujian Program}

Berikut ini hasil dari pengujian prototype program sistem pendukung keputusan konsentrasi dan peminatan program studi teknik informatika Univeritas Janabadra Yogyakarta yang telah dilakukan.

1. Tampilan Inputan Data Konsentrasi dan Peminatan Mahasiswa

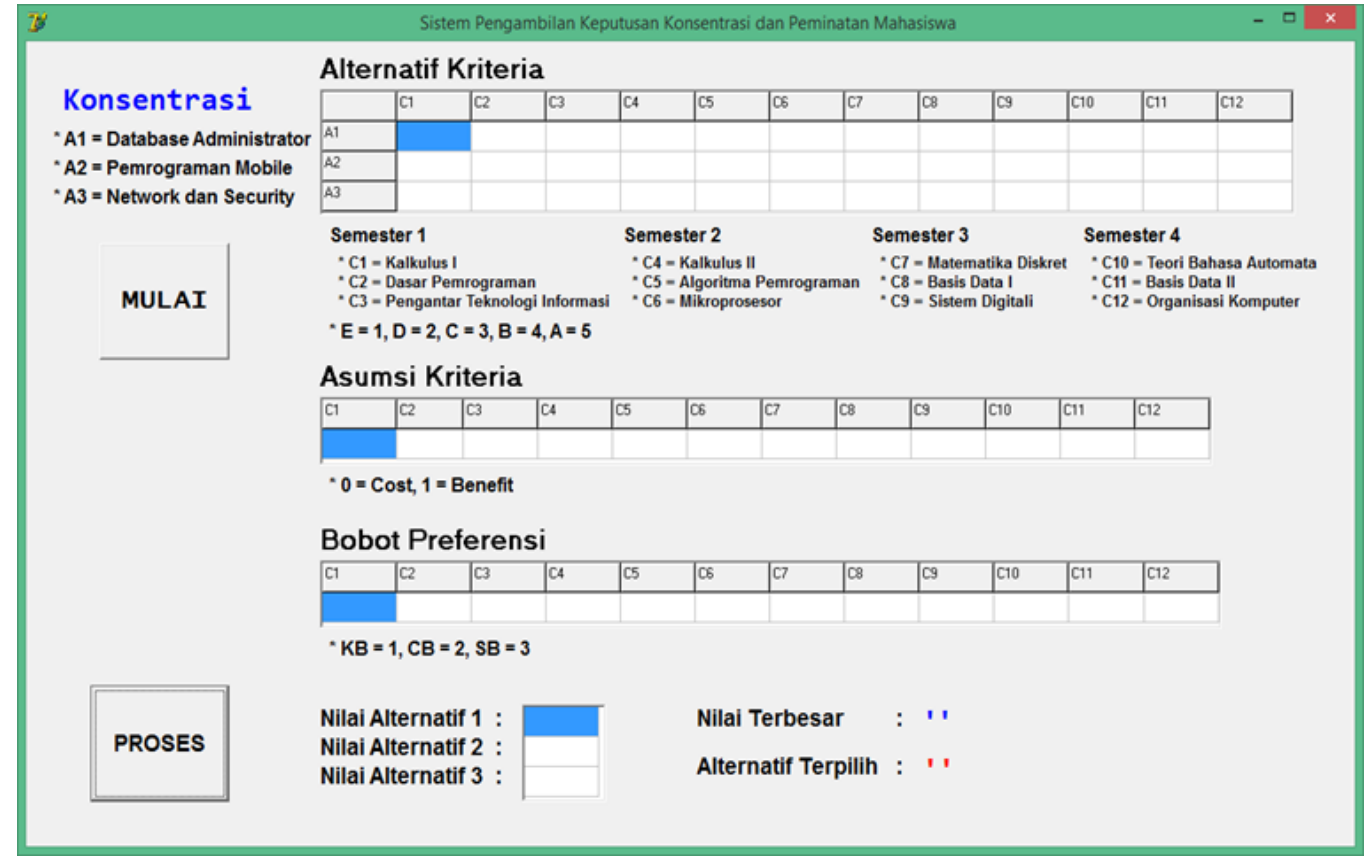

Gambar 6 . Tampilan Inputan Data Konsentrasi dan Peminatan Mahasiswa

Pada tampilan inputan pada Gambar 6 di atas, terdapat 3 menu inputan yang harus dimasukkan data. Menu inputan pertama yakni menu alternatif kriteria yang terdiri dari 12 kriteria merupakan nilai akademik mahasiswa dari semester 1 sampai dengan semester 4. Menu inputan kedua yakni menu asumsi kriteria, dimana asumsi kriteria dalam aplikasi ini semua bernilai benefit. Menu inputan ketiga yakni menu bobot preferensi yang merupakan nilai bobot untuk masing-mssing kriteria yang ada. 
Citec Journal, Vol. 3, No. 4, Agustus 2016 - Oktober 2016

2. Tampilan Alternatif terpilih Konsentrasi dan Peminatan Mahasiswa

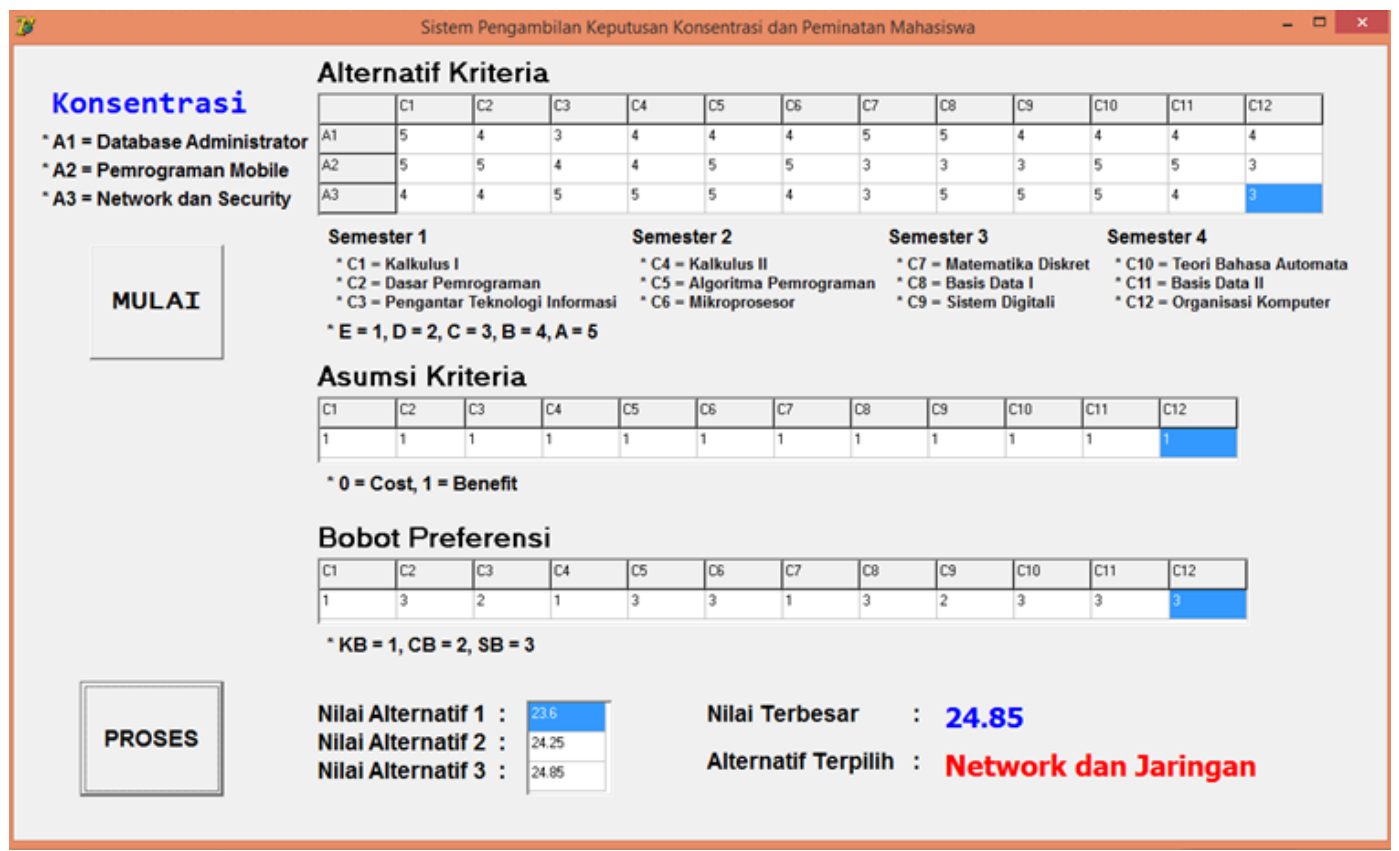

Gambar 7. Tampilan Alternatif terpilih Konsentrasi dan Peminatan Mahasiswa

Pada tampilan alternatif terpilih pada Gambar 7 di atas, merupakan proses perhitungan dari data hasil inputan yang telah di isi oleh pengguna, dimana untuk menu inputan alternatif kriteria di inputkan dengan angka 5 sampai dengan angka 1 yang menunjukkan nilai kepentingan pada bilangan fuzzy bobot kriteria. Sedangkan untuk inputan asumsi kriteria karena semua kriteria bernilai benefit maka nilai 1 (satu). Untuk bobot preferensi berdasarkan rating kecocokan setiap alternatif pada setiap kriteria dinilai dengan 1 sampai 3. Setelah semua data inputan sudah terisi, pada saat dilakukan proses perhitungan berdasarkan data inputan tersebut didapat nilai terbesar yakni 24,85 dengan alternatif terpilih Network dan Jaringan.

\section{KESIMPULAN}

Setelah melakukan analisis, merancang dan mengimplementasikan sistem pendukung keputusan konsentrasi dan peminatan program studi teknik informatika Universitas Janabadra Yogyakarta diperoleh kesimpulan sebagai berikut:

1. Sistem pendukung keputusan ini telah mampu memberikan alternatif solusi bagi pengambil keputusan dalam menentukan hasil akhir konsentrasi dan peminatan yang sesuai dengan mahasiswa, akan tetapi belum sampai pada taraf implementasi dan akan dilanjutkan pada penelitian selanjutnya.

2. Sistem Pendukung Keputusan ini memiliki 3 alternatif keputusan sebagai konsentrasi dan peminatan serta 12 kriteria dimana kriteria merupakan matakuliah yang telah ditentukan dari semester 1 sampai dengan semester 4.

3. Sistem pendukung keputusan ini masih dalam bentuk prototype, dalam pengujiannya masih menggunakan data dummy belum menggunakan data yang sesungguhnya untuk penentuan konsentrasi dan peminatan.

4. Sistem pendukung keputusan yang dibuat ini, akan dikembangkan lagi untuk penelitian selanjutnya guna melakukan perbandingan dengan penelitian yang sejenis. 


\section{SARAN}

Untuk meningkatkan kinerja dari sistem yang telah dibuat, maka penulis memberikan saran semoga dapat bermanfaat bagi pihak-pihak yang akan mengembangkan sistem pendukung keputusan ini ke depan, yaitu:

1. Perlu menambahkan kriteria yang tidak hanya berdasarkan dari nilai akademik saja bisa juga ditambahkan indeks prestasi mahasiswa, agar pemberian bobot sistem pendukung keputusan nantinya lebih akurat memberikan solusi dari konsentrasi dan peminatan.

2. Dapat menambahkan jumlah kriteria yang menjadi acauan dari nilai -nilai akademik yang digunakan dan bersifat cost.

3. Dibutuhkan sosialisasi yang lebih tentang sistem pendukung keputusan ini pada mahasiswa program studi teknik Informatika Universitas Janabadra Yogyakarta untuk mengoptimalkan kinerja sistem ini.

\section{DAFTAR PUSTAKA}

[1] Belmawa Ristek dikti, 2015, Panduan Penyusunan Capai Pembelajaran, http://belmawa. ristekdikti.go.id/dev/wp-content/uploads/2015/11/6A-Panduan-Penyusunan-CP.pdf, diakses $\operatorname{tgl} 6$ Juni 2016

[2] Fiyanti, S. D., 2015, Penentuan Peminatan Tugas Akhir Mahasiswa Teknik Informatika UNSIKA, Jurnal Ilmiah Solusi, No. 5, Vol. 2, Hal. 9-16

[3] Satria, R., Mustafidah, H., 2014, Penentuan Minat pada Program Studi Teknik Informatika Universitas Muhammadiyah Purwokerto Menggunakan Teori Dempster-Shafer, Jurnal Informatika, No. 2, Vol. 3, Hal 77-83

[4] Wang, Y. J., 2015, A Fuzzy Multi-Criteria Decision-Making Model Based on Simple Additive Weighting Method and Relative Preference Relation, Applied Soft Computing, Vol. 30, Hal. 412-420

[5] Budianita, E., Arni, U. D., 2015, Penerapan Learning Vector Quantization Penentuan Bidang Konsentrasi Tugas Akhir (Studi Kasus: Mahasiswa Teknik Informatika UIN Suska Riau), Jurnal CoreIT, No.2, Vol.1, Hal 85-89

[6] Jogianto, 2003, Sistem Teknologi Informasi, Penerbit Andi, Yogyakarta

[7] Kusrini, 2008, Konsep dan Aplikasi Sistem Pendukung Kuputusan, Penerbit Andi, Yogyakarta

[8] Kusumadewi, Sri, dkk. 2007, Fuzzy Multi- Attribute Decision Making, Penerbit Graha Ilmu, Yogyakarta

[9] Pressman, R. S., 2002, Rekayasa Perangkat Lunak Pendekataan Praktis (Buku I), Penerbit Andi, Yogyakarta 